\title{
Synthesis and Biological Evaluation of New (-)-Gossypol-Derived Schiff Bases and Hydrazones
}

\author{
Vu Van Vu, ${ }^{1}$ Trinh Thi Nhung, ${ }^{1}$ Nguyen Thi Thanh, ${ }^{1}$ Luu Van Chinh,, ${ }^{2}$ u Dinh Tien, \\ Vu Thu Thuy, ${ }^{1}$ Do Thi Thao, ${ }^{3}$ Nguyen Hai Nam, ${ }^{4}$ Angela Koeckritz, ${ }^{5}$ and Tran Khac Vu ${ }^{1}$ \\ ${ }^{1}$ School of Chemical Engineering, Hanoi University of Science and Technology, No. 1 Dai Co Viet, Hai Ba Trung, Hanoi, Vietnam \\ ${ }^{2}$ Institute of Natural Products Chemistry, Vietnam Academy of Science and Technology, 18 Hoang Quoc Viet, Cau Giay, Hanoi, Vietnam \\ ${ }^{3}$ Institute of Biotechnology, Vietnam Academy of Science and Technology, 18 Hoang Quoc Viet, Cau Giay, Hanoi, Vietnam \\ ${ }^{4}$ Hanoi University of Pharmacy (HUP), 13-15 Le Thanh Tong, Hanoi, Vietnam \\ ${ }^{5}$ Leibniz Institute for Catalysis at the University of Rostock, Albert-Einstein-Str. 29A, 18059 Rostock, Germany
}

Correspondence should be addressed to Tran Khac Vu; vu.trankhac@hust.edu.vn

Received 8 June 2017; Revised 19 August 2017; Accepted 13 September 2017; Published 17 October 2017

Academic Editor: Mire Zloh

Copyright (C) $2017 \mathrm{Vu}$ Van Vu et al. This is an open access article distributed under the Creative Commons Attribution License, which permits unrestricted use, distribution, and reproduction in any medium, provided the original work is properly cited.

\begin{abstract}
A series of 14 new (-)-gossypol Schiff bases and hydrazones have been synthesized via an in situ procedure in high yields. Structural data showed that all target compounds exist as the enamine tautomer. Bioassays showed that several compounds exhibited cytotoxic effects against three human cancer cell lines. Compound 8a showed the greatest cytotoxic effect against hepatocellular carcinoma (HepG2), lung carcinoma (LU-1), and breast cancer (MCF-7) cell lines with $\mathrm{IC}_{50}$ values of 20.93, 13.58, and 9.40 $\mu \mathrm{M}$, respectively. However, in an antibacterial test, compounds $\mathbf{8 a}$ and $\mathbf{8 b}$ inhibited Staphylococcus aureus and Bacillus cereus and compound $\mathbf{8 e}$ inhibited only Staphylococcus aureus at the same MIC values of $1024 \mu \mathrm{g} / \mathrm{ml}$.
\end{abstract}

\section{Introduction}

Cancer is characterized by uncontrolled cell growth, metastasis, and invasion and is responsible for approximately $13 \%$ of all human deaths throughout the world [1]. The three most common and fatal types are lung, liver, and breast cancer. Currently, although there has been a lot of success in both cancer chemotherapy and anticancer drug development research, cancer remains a significant challenge in the future because of the drug resistance and adverse side effects of chemotherapy [2]. Novel antitumor agents based on natural products are becoming increasingly more popular in order to overcome these limitations and develop more effective anticancer agents [3].

Gossypol (1) (Figure 1), a polyphenolic dialdehyde found in high concentrations in the pigment glands of the cotton plant Gossypium, has recently received increased attention due to its wide range of biological activities, especially anticancer [4-7], contraceptive [8], antiviral [9-11], and antimicrobial [12] activities. However, the application of gossypol as a therapeutic agent has been limited because of a number of serious side effects [13] that have been shown to be associated with the aldehyde groups. More recently, significant attention has been focused on the potential therapeutic value of gossypol as a promising starting point for the development of antitumor or antiviral derivatives for medicinal applications with enhanced bioactivity and reduced side effects [14-18], in which the aldehyde groups are altered to give gossypol derivatives (e.g., Schiff bases, esters, and ethers). Many of these derivatives exhibit a variety of unusual disease-inhibiting activities, especially anticancer activity [19]. Research regarding the biological effects of gossypol both in vitro and in vivo showed that the (-)enantiomer is more potent than the $(+)$-enantiomer or the racemic mixture (1) [20]. It has also been hypothesized that while low doses of (-) gossypol are selective, higher doses of either enantiomer result in nonselective action [21, 22]. Also related to the mechanism of action, (-)-gossypol has been reported to target $\mathrm{Bcl}-2, \mathrm{Bcl}-\mathrm{xL}$, and $\mathrm{Mcl}-1$ proteins with high affinities and is now in clinical trials as an orally administered 


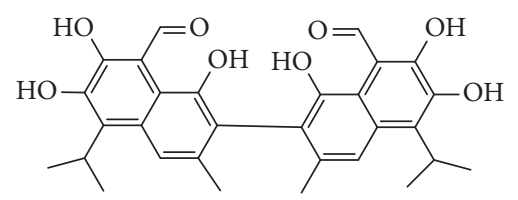

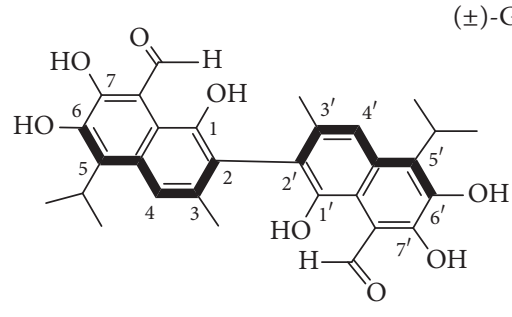

$R-(-)-G o s s y p o l(2)$

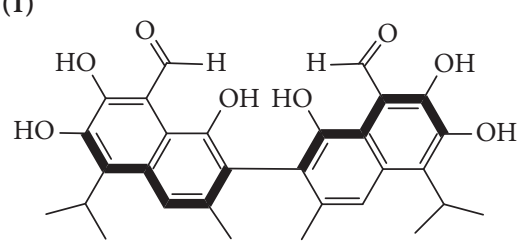

S-(+)-Gossypol (3)

FIGURE 1: Racemic gossypol and its enantiomers.

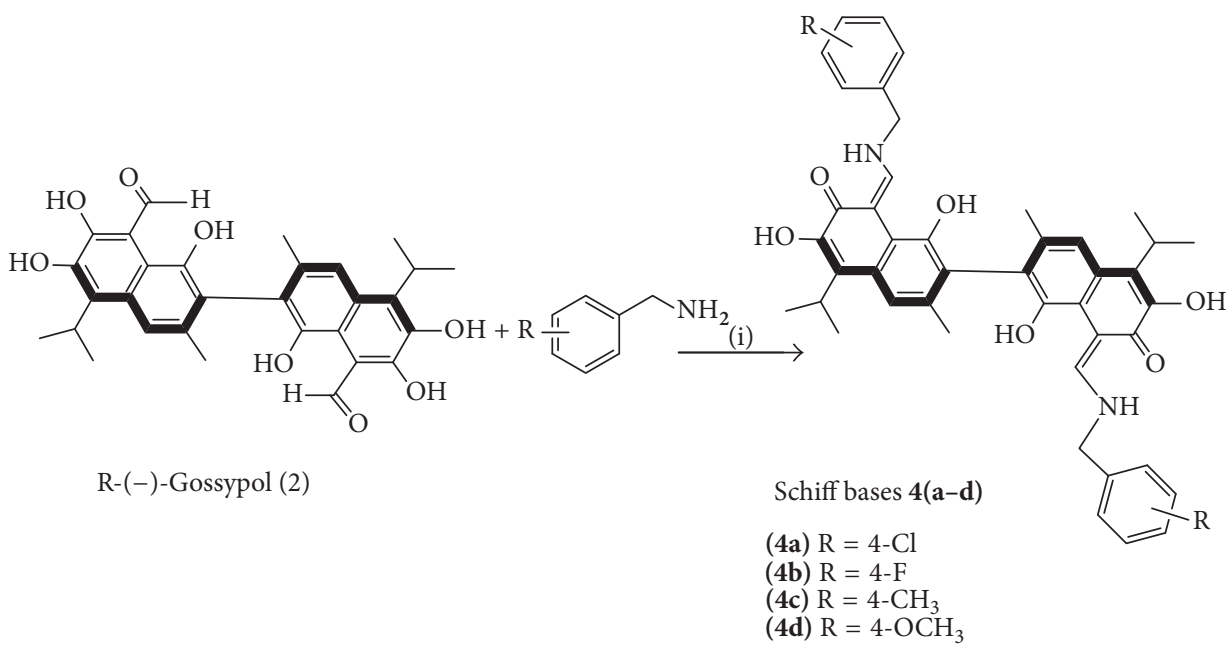

Scheme 1: Synthesis of (-)-gossypol Schiff bases 4a-d; (i) EtOH, 8 h, r.t, 60.7-81.8\%.

agent for the treatment of several types of human cancer $[21,22]$. Intrigued by this observation, we synthesized and evaluated new (-)-gossypol hydrazones for their cytotoxic effects against three human cancer cell lines. This paper reports the results of this study.

\section{Results and Discussion}

2.1. Chemistry. New Schiff bases and hydrazones of (-)gossypol were synthesized as outlined (Schemes 1-3). The starting material (-)-gossypol was first prepared according to a known procedure with modification [23], using L-tryptophan methyl ester as an effective agent for the resolution of racemic gossypol. The yield of (-)-gossypol (2) obtained was comparable to that reported in the literature [23] (see Supplementary Material available online at https://doi.org/10.1155/2017/3687182).

Schiff bases $\mathbf{4 a - d}$ were synthesized (Scheme 1). The reactions of (-)-gossypol (2) with primary amines including 4-chlorobenzylamine, 4-fluorobenzylamine, 4-methylbenzylamine, and 4-methoxybenzylamine were conducted in ethanol at room temperature for $8 \mathrm{~h}$. The resulting Schiff bases $\mathbf{4 a}-\mathbf{d}$ were obtained by simple filtering and washing with methanol and dichloromethane. The NMR data showed the enamine-enamine tautomer of these Schiff bases via characteristic chemical shifts of $\mathrm{NH}$ protons resulting from hydrogen bonding formation ranging from 13.34 to $13.49 \mathrm{ppm}$ in the ${ }^{1} \mathrm{H}$ NMR spectrum [24]. In the ${ }^{13} \mathrm{C}$ NMR spectrum, the chemical shifts of ketone C-7 were observed at the lowest field from 171.9 to $172.3 \mathrm{ppm}$, followed by the chemical shifts of C-6 around 162 ppm. The chemical shifts of C-1 were easily observed at around $149 \mathrm{ppm}$.

Novel hydrazones 8a-e were synthesized in a three-step procedure as outlined (Scheme 2). First, benzoic acid derivatives $5 \mathbf{a}-\mathbf{e}$ were converted to the corresponding esters $\mathbf{6 a}-\mathbf{e}$ in quantitative yields by Fisher esterification. These esters were then refluxed with hydrazine hydrate $(80 \%)$ in ethanol to give the corresponding hydrazides (7a-e) in high yields, which were then used for the next step without further purification. Unlike the case of Schiff bases $\mathbf{4 a}-\mathbf{d}$, hydrazides $(7 \mathbf{a}-\mathbf{e})$ were less active than the primary amines. Initially, hydrazides (7a-e) were reacted with (-)-gossypol (2) in ethanol at room 


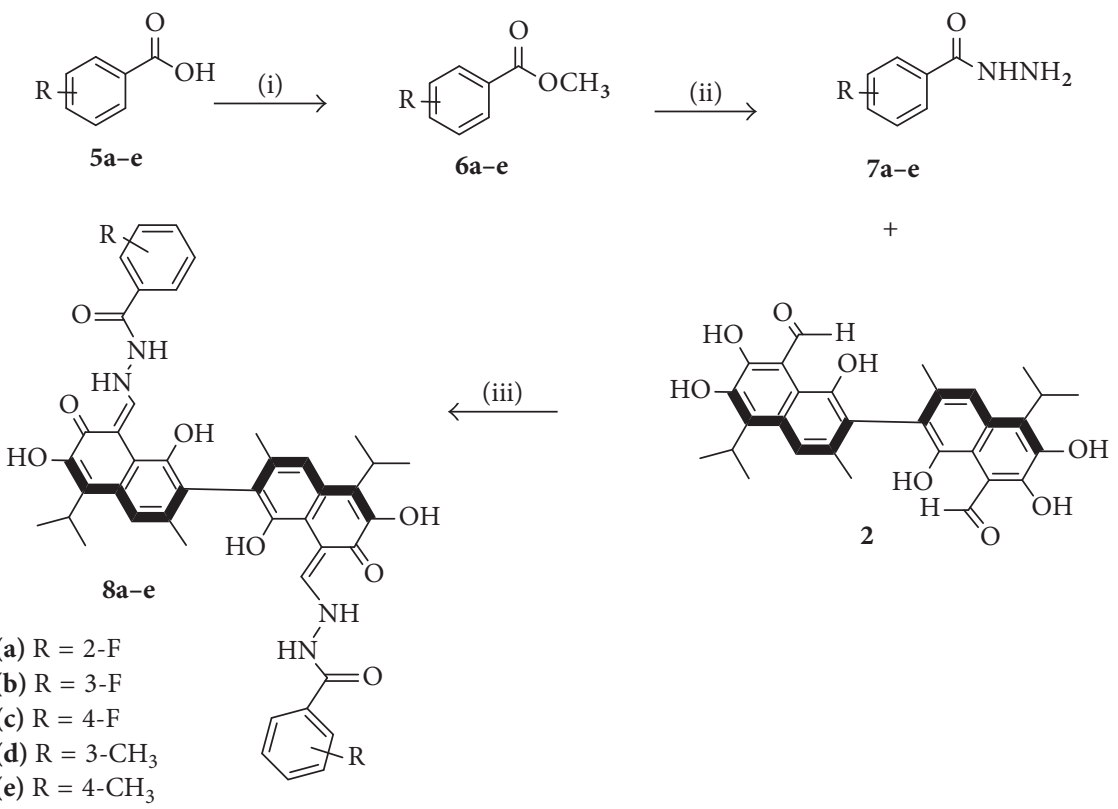

Scheme 2: Synthesis of (-)-gossypol hydrazone 8a-e; (i) $\mathrm{MeOH}_{2} \mathrm{H}_{2} \mathrm{SO}_{4}, \mathrm{MeOH}$, reflux, 12 h; (ii) EtOH, $\mathrm{NH}_{2} \mathrm{NH}_{2}$ (80\%), r.t, 10 h; (iii) EtOH, $\mathrm{ZnCl}_{2}$, r.t, 16 h, 50.4-63.0\%.
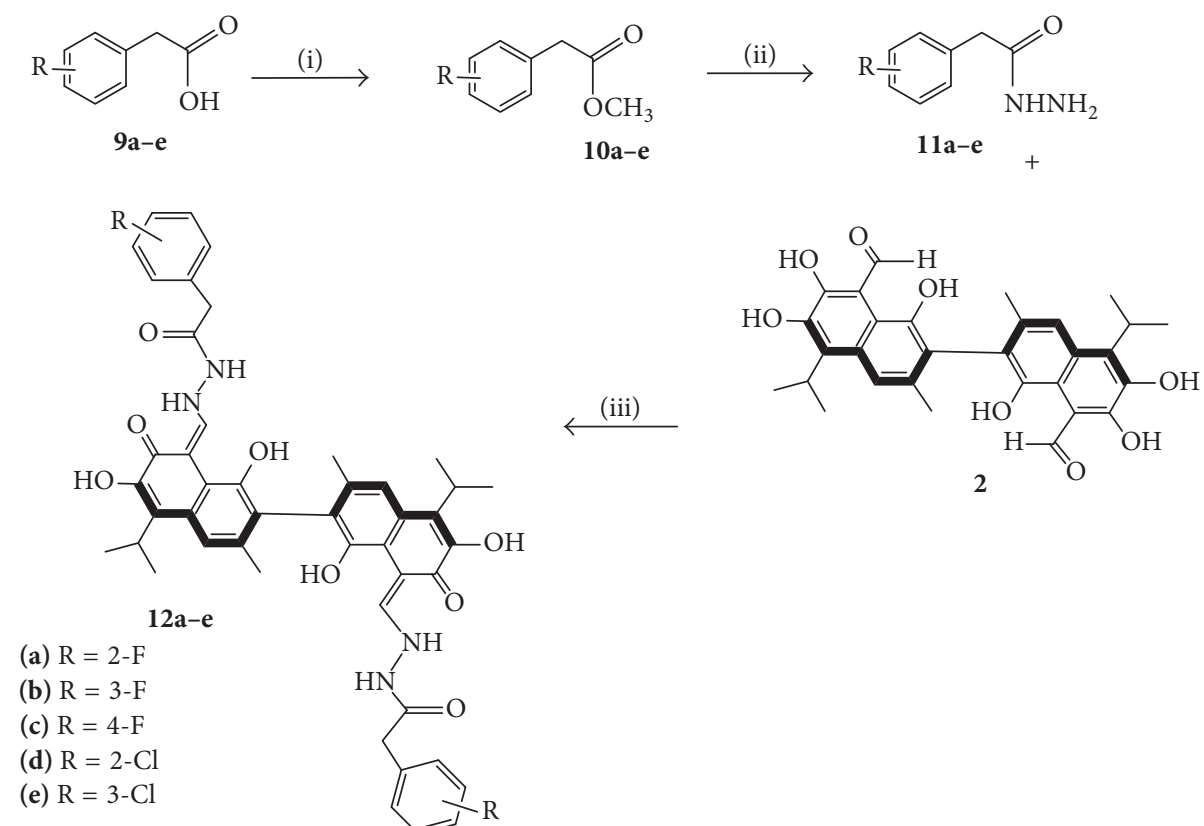

Scheme 3: Synthesis of hydrazones 12a-e; (i) $\mathrm{MeOH}, \mathrm{H}_{2} \mathrm{SO}_{4}$, $\mathrm{MeOH}$, reflux, 12 h; (ii) EtOH, $\mathrm{NH}_{2} \mathrm{NH}_{2}$ (80\%), r.t, 10 h; (iii) EtOH, ZnCl 2 , r.t, $12 \mathrm{~h}, 48.7-53.0 \%$.

temperature for $16 \mathrm{~h}$ with very poor yields. The reaction was next carried out at reflux but failed to give the desired products owing to the decomposition of gossypol. Hydrazones are easily prepared in the presence of acetic acid as a catalyst. However, the reaction of $\mathbf{7 a - e}$ with (-)-gossypol did not proceed as expected in the presence of acetic acid. In this study, $\mathrm{ZnCl}_{2}$ was examined and found to be an excellent catalyst for the hydrazone formation. The reaction of hydrazides $(7 \mathbf{a}-\mathbf{e})$ with (-)-gossypol (2) in the presence of a small amount of
$\mathrm{ZnCl}_{2}$ led to the formation of a series of hydrazones (8a-e) in high yields. To the best of our knowledge, this is the first time that $\mathrm{ZnCl}_{2}$ has been used as an effective catalyst for the synthesis of new gossypol hydrazones (8a-e). An analysis of ${ }^{1} \mathrm{H}$ and ${ }^{13} \mathrm{C}$ NMR spectra data showed that hydrazones 8a-e exist as the enamine-enamine tautomer [24].

Compound $\mathbf{8 c}$ was used as an example for the structural elucidation of hydrazones. The ${ }^{1} \mathrm{H}$ NMR spectrum of compound $\mathbf{8 c}$ showed the characteristic resonance signal of 
$\mathrm{NH}$ at the lowest field $\delta 14.76 \mathrm{ppm}$ due to hydrogen bonding with the adjacent ketone group. The chemical shift at $\delta$ $12.39 \mathrm{ppm}$ is attributed to the other $\mathrm{NH}$ group. Additionally, the resonance signal at $\delta 10.19 \mathrm{ppm}$ as a sharp singlet is also attributed to $6-\mathrm{OH}$. The vinylic proton in the enamine is easily observed as a single peak at $8.81 \mathrm{ppm}$; signals at higher field belonging to the protons $\mathrm{H}-4$ and $1-\mathrm{OH}$ at $\delta 8.16$ and $7.63 \mathrm{ppm}$, respectively, are coupled. Besides, the presence of the aromatic ring protons can be observed as doublets $(J=$ $8.0 \mathrm{~Hz})$ at $\delta 8.02$ and $7.37 \mathrm{ppm}$. The ${ }^{13} \mathrm{C}$ NMR showed all the signals of the gossypol skeleton and aromatic rings in which the signals at 165.2 and $163.3 \mathrm{ppm}$ are attributed to C7 and C-6, respectively. The carbon connected to Fluorine in the aromatic ring resonates at $\delta 161.7 \mathrm{ppm}$, based on the characteristic splitting of Fluorine and the hydrazide carbonyl at $\delta 153.2 \mathrm{ppm}$.

Novel hydrazones 12a-e were synthesized in the same way as mentioned above, starting from different phenylacetic acid derivatives (9a-e) (Scheme 3). The structure of synthesized hydrazones was confirmed similarly, based on NMR and mass spectroscopy data.

\section{Biological Activity}

The in vitro cytotoxic evaluation of the synthesized compounds was carried out according to the described protocol [25]. Briefly, a stock solution of the target compound was prepared in dimethylsulfoxide (DMSO) at a concentration of $1 \mathrm{mg} / \mathrm{mL}$, followed by dilution to obtain a solution at a concentration of $100 \mu \mathrm{g} / \mathrm{mL}$, which was serially diluted further for bioassays in 96-well plates. The determination of IC $_{50}$ was carried out using three cancer cell lines, HepG2, LU1, and MCF-7, with ellipticine and (-)-gossypol as positive controls. The $\mathrm{IC}_{50}$ values were determined from a dosedependent curve plotted from five different concentration regimens $(0-100 \mu \mathrm{M})$. At each regimen, mean of triplicate experiment was used for a point in the curve. The bioassay results are described in Table 1.

The bioassay results (Table 1) showed that only half of the target compounds exhibited cytotoxic effects against cancer cell lines tested, ranging from 9.40 to $99.55 \mu \mathrm{M}$. Unexpectedly, Schiff bases $\mathbf{4 a - c}$, bearing both electron withdrawing groups $(\mathrm{Cl}$ and $\mathrm{F})$ and an electron donating group $\left(\mathrm{CH}_{3}\right)$ at the para position of the aromatic ring, showed no cytotoxicity against all three cell lines except compound 4d, which contains an electron donating group $\left(\mathrm{OCH}_{3}\right) .4 \mathbf{d}$ revealed a weak inhibitory effect against only the LU-1 cell line. For hydrazones 12a-e, compounds 12c-e containing electron withdrawing groups at ortho, meta, and para positions were inactive against all cell lines. However, compounds 12a and $\mathbf{1 2 b}$ containing electron withdrawing groups at ortho and para positions exhibited weak-to-moderate cytotoxic effects. The observation also shows that cytotoxic effects of hydrazones 8a-e derived from benzoic acid derivatives were better than those of phenyl acetic acid derivatives, excluding compound $\mathbf{8 e}$, and that series $\mathbf{8 a}-\mathbf{d}$ were more cytotoxic towards MCF7 and LU-1 than towards HepG2 cell line. It seems that the electron withdrawing group $(\mathrm{F})$ at ortho position contributes towards greater toxicity compared to the meta position. In terms of $\mathrm{IC}_{50}$ values, all synthesized hydrazones exhibited less potency than that of the control, ellipticine, or the parent (-)-gossypol and some other gossypol derivatives reported $[16,17]$. Regarding mechanism of action, most of gossypol derivatives were reported to target Bcl-2 family proteins [20]. In this study, it is early and hard to come up with a mechanism of action at this stage without predicted binding models of designed hydrazones to such target protein as $\mathrm{Bcl}-2$ or Mcl-1 [20-22]. However, it can be predicted that such possible target proteins as Bcl-2 or Mcl-1 participate in the mechanism of action.

Among synthesized hydrazones, compound 8a showed the best cytotoxic effect against HepG2, LU-1, and MCF-7 with $\mathrm{IC}_{50}$ values of $20.93,13.58$, and $9.40 \mu \mathrm{M}$, respectively. Accordingly, this compound could be considered as a lead for future design of gossypol hydrazones in which bioisosteric replacements in ortho position of the phenyl ring could be performed to improve the cytotoxic activity.

In order to expand the biological spectrum of gossypol derivatives, synthesized hydrazones were also evaluated for antibacterial activity against human pathogenic bacteria, including Staphylococcus aureus (ATCC 6538), Bacillus cereus (ATCC 21768), Bacillus subtilis (ATCC 6633), Escherichia coli (ATCC 25931), and Pseudomonas aeruginosa (ATCC 9027), according to described protocol [26]. Briefly, five bacterial species including two Gram-negative strains (Escherichia coli ATCC 25931 and Pseudomonas aeruginosa ATCC 9027) and three Gram-positive strains (Bacillus subtilis ATCC 6633, Bacillus subtilis ATCC 6633, and Staphylococcus aureus ATCC 6538) were obtained from the ATCC (Manassas, VA, USA). The bacterial strains were cultured aerobically on nutrient agar (NA) plates at $37^{\circ} \mathrm{C}$ for $24 \mathrm{~h}$. For the antibacterial activity test, the bacteria were aerobically cultured in nutrient broth $(\mathrm{NB})$ at $37^{\circ} \mathrm{C}$ for $24 \mathrm{~h}$ and then suspended in sterile saline at a density equivalent to that of the $0.5 \mathrm{McF}$ arland standards. Bacterial suspensions with a concentration of $105 \mathrm{cfu} / \mathrm{ml}$ were used for in vitro antibacterial activity test.

The results (Table 2) showed that most of the synthesized hydrazones were inactive against the bacteria tested. Compounds 8a and $\mathbf{8 b}$ inhibited Staphylococcus aureus and Bacillus cereus and 8e inhibited only Staphylococcus aureus at the same MIC values of $1024 \mu \mathrm{g} / \mathrm{ml}$ and showed less bacterial activity than that of the parent compound, (-)gossypol and some aza-derivatives of gossypol [24]. From the structure activity relationship, inactivity or weak activity of new hydrazones can be a result of the presence in its structure of the moieties attached to gossypol, which probably do not enable better interaction of these derivatives with the lipid bilayer of bacteria.

\section{Conclusions}

We have presented the synthesis of new Schiff bases and hydrazones of (-)-gossypol and screened for in vitro cytotoxic activity against several human cancer cell lines and antibacterial activity against human pathogenic bacteria. In this research, for the first time, $\mathrm{ZnCl}_{2}$ has been effectively used for the synthesis of gossypol hydrazones. Although no compounds were as effective as positive controls or gossypol 
TABLE 1: Cytotoxic activity of target compounds.

\begin{tabular}{|c|c|c|c|c|}
\hline \multirow{2}{*}{ Number } & \multirow{2}{*}{ Compounds } & \multicolumn{3}{|c|}{$\mathrm{IC}_{50}(\mu \mathrm{M})$} \\
\hline & & HepG2 & LU-1 & MCF-7 \\
\hline (1) & $4 a$ & $>100$ & $>100$ & $>100$ \\
\hline (2) & $4 b$ & $>100$ & $>100$ & $>100$ \\
\hline (3) & $4 c$ & $>100$ & $>100$ & $>100$ \\
\hline (4) & $4 d$ & $>100$ & 66.83 & $>100$ \\
\hline (5) & $8 \mathbf{a}$ & 20.93 & 13.58 & 9.40 \\
\hline (6) & $8 b$ & 55.82 & 56.82 & 48.48 \\
\hline (7) & $8 \mathrm{c}$ & 89.72 & 79.83 & 86.40 \\
\hline (8) & $8 d$ & 86.46 & 64.56 & 65.72 \\
\hline (9) & $8 e$ & $>100$ & $>100$ & $>100$ \\
\hline (10) & $12 a$ & 55.68 & 54.70 & 63.33 \\
\hline (11) & $12 b$ & 95.30 & 99.55 & $>100$ \\
\hline (12) & $12 \mathrm{c}$ & $>100$ & $>100$ & $>100$ \\
\hline (13) & $12 d$ & $>100$ & $>100$ & $>100$ \\
\hline (14) & $12 \mathrm{e}$ & $>100$ & $>100$ & $>100$ \\
\hline (15) & Ellipticine & 1.71 & 1.87 & 1.91 \\
\hline (16) & (-)-Gossypol & 4.5 & 4.3 & 4.0 \\
\hline
\end{tabular}

Note. The reference substance, ellipticine, exhibited cytotoxic activity against HepG2 (ATCC-HB 8065), LU-1 (ATCC-HTB-57), and MCF-7 (ATCC- HTB22) with $\mathrm{IC}_{50}$ values of $1.71,1.87$, and $1.91 \mu \mathrm{M}$, respectively. The values shown for these compounds are the average of three determinations.

TABLE 2: Antibacterial activity of compounds against human pathogenic bacteria.

\begin{tabular}{|c|c|c|c|c|c|c|}
\hline \multirow{2}{*}{ Number } & \multirow{2}{*}{ Compounds } & \multicolumn{5}{|c|}{$\operatorname{MIC}(\mu \mathrm{g} / \mathrm{ml})$} \\
\hline & & $\begin{array}{c}\text { Staphylococcus } \\
\text { aureus (ATCC 6538) }\end{array}$ & $\begin{array}{l}\text { Bacillus cereus } \\
\text { (ATCC 21768) }\end{array}$ & $\begin{array}{c}\text { Bacillus subtilis } \\
\text { (ATCC 6633) }\end{array}$ & $\begin{array}{l}\text { Escherichia coli } \\
\text { (ATCC 25931) }\end{array}$ & $\begin{array}{c}\text { Pseudomonas } \\
\text { aeruginosa (ATCC } \\
9027 \text { ) }\end{array}$ \\
\hline (1) & $4 a$ & - & - & - & - & - \\
\hline (2) & $4 b$ & - & - & - & - & - \\
\hline (3) & $4 c$ & - & - & - & - & - \\
\hline (4) & $4 d$ & - & - & - & - & - \\
\hline (5) & $8 a$ & 1024 & 1024 & & - & - \\
\hline (6) & $8 b$ & 1024 & - & 1024 & - & - \\
\hline (7) & $8 \mathrm{c}$ & - & - & - & - & - \\
\hline (8) & $8 d$ & - & - & - & - & - \\
\hline (9) & $8 e$ & 1024 & - & - & - & - \\
\hline (10) & $12 a$ & - & - & - & - & - \\
\hline (11) & $12 \mathrm{~b}$ & - & - & - & - & - \\
\hline (12) & $12 \mathrm{c}$ & - & - & - & - & - \\
\hline (13) & $12 d$ & - & - & - & - & - \\
\hline (14) & $12 \mathrm{e}$ & - & - & - & - & - \\
\hline (15) & Streptomycin sulfate & 20 & 20 & 5 & 20 & 20 \\
\hline (16) & (-)-Gossypol & 15 & 15 & 16 & $\mathrm{Nd}^{*}$ & $\mathrm{Nd}^{*}$ \\
\hline
\end{tabular}

${ }^{*}$ Not determined.

in terms of biological effects, the research could make contribution to the discovery of new gossypol derivatives based on research published herein.

\section{Experimental}

All chemicals and reaction solvents were purchased from Merck and Sigma-Aldrich. Melting points were determined in open capillaries on a Shimadzu Electrothermal IA 9200 apparatus and uncorrected. IR spectra were recorded on a Impact 410 FTIR using $\mathrm{KBr}$ discs. $1 \mathrm{D}-\mathrm{NMR}$ and $2 \mathrm{D}$ NMR Spectra were recorded on a Bruker AVANCE $500 \mathrm{MHz}$ spectrometer in $\mathrm{CDCl}_{3}$ and DMSO- $\mathrm{d}_{6}$. Chemical shifts $(\delta)$ are in ppm relative to TMS; multiplicities are shown as follows: $\mathrm{s}$ (singlet), $\mathrm{d}$ (doublet), $\mathrm{t}$ (triplet), and $\mathrm{m}$ (multiplet); and coupling constants $(J)$ are expressed in hertz $(\mathrm{Hz})$. HRMS 
was recorded by using a FT-ICR MS and ESI-TOF-MS Agilent 6230 spectrophotometer (Varian). Progress of the reaction was monitored by thin-layer chromatography (TLC) using precoated TLC sheets with ultraviolet (UV) fluorescent silica gel (Merck 60F254) and spots were visualized by UV lamp at $254 \mathrm{~nm}$. Column chromatography was carried out using silica gel (40-230 mesh).

5.1. Separation of (-)-Gossypol from ( \pm )-Gossypol. A solution of L-tryptophan methyl ester hydrochloride $(9.824 \mathrm{~g}$, $0.038 \mathrm{~mol})$ and $\mathrm{NaOH}(1.52 \mathrm{~g}, 0.038 \mathrm{~mol})$ in ethanol $(60 \mathrm{~mL})$ was stirred at $45^{\circ} \mathrm{C}$, and the racemic gossypol $(9.85 \mathrm{~g}$, $0.019 \mathrm{~mol}$ ) was added. The mixture was stirred for $2 \mathrm{~h}$. The reaction was monitored by TLC and then allowed to warm to room temperature. The resulting precipitate from the reaction was then filtered, washed with cold ethanol, and dried under reduced pressure to obtain Schiff base intermediate $(8.28 \mathrm{~g}$, 95\%). Schiff base intermediate $(8.808 \mathrm{~g}, 9.59 \mathrm{mmol})$ was dissolved in a mixture of acetic acid and ether $(4: 1)(50 \mathrm{~mL})$. The reaction mixture was kept at $-5-0^{\circ} \mathrm{C}$ under nitrogen atmosphere, and concentrated hydrochloric acid $(1.5 \mathrm{~mL})$ was slowly added for 10 minutes. The reaction was then stirred at room temperature for 72 and monitored by TLC. After the completion of reaction, the resulting D-tryptophan methyl ester was filtered and washed by an amount of dichloromethane. The filtrate was concentrated to dryness and was dissolved in $30 \mathrm{~mL}$ of mixture of dichloromethane and $n$-hexane $(2: 1)$ and was kept at $4^{\circ} \mathrm{C}$ for crystallization. (-)-Gossypol was obtained by filtering and washing with cold acetone in $85.2 \%$ yield ( $4.23 \mathrm{~g}), 94.4 \%$ ee by HPLC.

5.2. General Procedure for the Synthesis of Schiff Bases $(4 \boldsymbol{a}-\boldsymbol{d})$. A mixture of (-)-gossypol (100 mg, $1 \mathrm{eq}$, and $0.193 \mathrm{mmol}$ ) and corresponding amines $(2.2 \mathrm{eq}, 0.42 \mathrm{mmol}$ ) in $\mathrm{EtOH}$ $(10 \mathrm{~mL})$ was stirred at room temperature for $8 \mathrm{~h}$. The resulting precipitate was then filtered and washed with cold methanol and dichloromethane to afford desired Schiff bases $\mathbf{4 a - d}$.

$\left(R, 8 Z, 8^{\prime} Z\right)-8,8^{\prime}$-Bis(((4-chlorobenzyl)amino)methylene) $-1,1^{\prime}$, $6,6^{\prime}$-tetrahydroxy-5, $5^{\prime}$-diisopropyl-3,3'-dimethyl- $\left[2,2^{\prime}\right.$ - binaphthalene]-7, $7^{\prime}\left(8 H, 8^{\prime} H\right)$-dione $(4 a)$. Yield $77.8 \%$; mp: $227-$ $229^{\circ} \mathrm{C} ;{ }^{1} \mathrm{H}$ NMR (500 MHz, DMSO-d6): 13.45 (t, $J=5.5 \mathrm{~Hz}$, $2 \mathrm{H}, \mathrm{NH}), 9.85(\mathrm{~d}, J=12.5 \mathrm{~Hz}, 2 \mathrm{H}), 8.37$ (s, 2H), 7.83 (s, $2 \mathrm{H}), 7.44(\mathrm{~m}, 3 \mathrm{H}), 7.39(\mathrm{~d}, J=8.5 \mathrm{~Hz}, 4 \mathrm{H}), 4.75(\mathrm{~m}, 4 \mathrm{H}$, $\left.\mathrm{ArCH}_{2}\right), 3.69\left(\mathrm{~m}, 2 \mathrm{H}, \mathrm{CH}\left(\mathrm{CH}_{3}\right)_{2}\right), 1.94\left(\mathrm{~s}, 6 \mathrm{H}, 2 \mathrm{CH}_{3}\right)$, $1.43\left(\mathrm{t}, \mathrm{J}=7.0 \mathrm{~Hz}, 12 \mathrm{H}, 4 \mathrm{CH}_{3}\right) \cdot{ }^{13} \mathrm{C} \mathrm{NMR}(125 \mathrm{MHz}$, DMSO-d6): 172.2, 162.4, 149.6, 146.2, 136.7, 132.4, 131.4, 129.4, $128.7,126.9,126.7,120.3,116.6,115.8,103.5,52.3,26.5,20.3$, 20.14. HR-ESIMS $[\mathrm{M}+\mathrm{H}]^{+}$found 765.24945; calculated $\mathrm{C}_{44} \mathrm{H}_{43} \mathrm{Cl}_{2} \mathrm{~N}_{2} \mathrm{O}_{6}: 765.24982$.

$\left(R, 8 Z, 8^{\prime} Z\right)-8,8^{\prime}$-Bis(((4-fluorobenzyl)amino)methylene)-1,1', $6,6^{\prime}$-tetrahydroxy-5, $5^{\prime}$-diisopropyl-3,3'-dimethyl- $\left[2,2^{\prime}\right.$ - binaphthalene]-7, $7^{\prime}\left(8 H, 8^{\prime} H\right)$-dione (4b). Yield 81.8\%; mp: $223-$ $225^{\circ} \mathrm{C} ;{ }^{1} \mathrm{H}$ NMR (500 MHz, DMSO-d6): 13.47 (t, $J=5.0 \mathrm{~Hz}$, $2 \mathrm{H}, \mathrm{NH}), 9.87$ (d, $J=12.5 \mathrm{~Hz}, 2 \mathrm{H}), 8.37$ (s, 2H), $7.84(\mathrm{~s}, 2 \mathrm{H})$, 7.45-7.37 (m, 6H), 7.21 (m, 4H), 4.74 (brs, 4H, $\mathrm{ArCH}_{2}$ ), 3.70 $\left(\mathrm{m}, 2 \mathrm{H}, \mathrm{CH}\left(\mathrm{CH}_{3}\right)_{2}\right), 1.94\left(\mathrm{~s}, 6 \mathrm{H}, 2 \mathrm{CH}_{3}\right), 1.43(\mathrm{t}, J=6.5 \mathrm{~Hz}$, $\left.12 \mathrm{H}, 4 \mathrm{CH}_{3}\right) .{ }^{13} \mathrm{C}$ NMR (125 MHz, DMSO-d6): 172.1, 162.6,
$162.3,160.7,149.6,146.2,133.8,131.3,129.6,126.9,126.7,120.3$, $116.6,115.6,103.4,52.3,26.5,20.3,20.1$. HR-ESIMS $[\mathrm{M}+\mathrm{H}]^{+}$ found 733.30890; calculated $\mathrm{C}_{44} \mathrm{H}_{43} \mathrm{~F}_{2} \mathrm{~N}_{2} \mathrm{O}_{6}$ : 733.30892 .

$\left(R, 8 Z, 8^{\prime} Z\right)-8,8^{\prime}-B i s(((4-m e t h y l b e n z y l)$ amino $)$ methylene $)-1,1^{\prime}$, $6,6^{\prime}$-tetrahydroxy-5, $5^{\prime}$-diisopropyl-3,3' -dimethyl- $\left[2,2^{\prime}\right.$-binaphthalene]-7, $7^{\prime}\left(8 H, 8^{\prime} H\right)$-dione (4c). Yield 60.7\%; mp: 211$213^{\circ} \mathrm{C} ;{ }^{1} \mathrm{H}$ NMR $(500 \mathrm{MHz}$, DMSO-d6): 13.49 (t, $J=6.0 \mathrm{~Hz}$, $2 \mathrm{H}, \mathrm{NH}), 9.88$ (d, $J=12.5 \mathrm{~Hz}, 2 \mathrm{H}), 8.36$ (s, 2H), $7.86(\mathrm{~s}, 2 \mathrm{H})$, 7.45 (s, 2H), 7.26 (d, $J=8.0 \mathrm{~Hz}, 4 \mathrm{H}, \mathrm{Ar}), 7.19$ (d, $J=8.0 \mathrm{~Hz}$, $4 \mathrm{H}, \mathrm{Ar}), 4.70(\mathrm{~m}, 4 \mathrm{H}, \mathrm{ArCH} 2), 3.69\left(\mathrm{~m}, 2 \mathrm{H}, \mathrm{CH}\left(\mathrm{CH}_{3}\right)_{2}\right)$, $2.28\left(\mathrm{~s}, \mathrm{CH}_{3}\right), 1.93\left(\mathrm{~s}, 6 \mathrm{H}, 2 \mathrm{CH}_{3}\right), 1.43(\mathrm{t}, J=7.0 \mathrm{~Hz}, 12 \mathrm{H}$, $\left.4 \mathrm{CH}_{3}\right) .{ }^{13} \mathrm{C}$ NMR (125 MHz, DMSO-d6): 171.9, 162.4, 149.7, $146.2,136.9,134.5,131.3,129.3,128.7,127.5,126.6,126.6,120.2$, $115.8,103.4,52.9,26.5,20.6,20.2,20.1$. HR-ESIMS $[\mathrm{M}+\mathrm{H}]^{+}$ found 725.35891; calculated $\mathrm{C}_{46} \mathrm{H}_{49} \mathrm{~N}_{2} \mathrm{O}_{6}$ : 725.35906 .

$\left(R, 8 Z, 8^{\prime} Z\right)-8,8^{\prime}$-Bis(((4-methoxybenzyl)amino)methylene)$1,1^{\prime}, 6,6^{\prime}$-tetrahydroxy-5, $5^{\prime}$-diisopropyl-3,3' -dimethyl- $\left[2,2^{\prime}\right.$ - binaphthalene]-7, $7^{\prime}\left(8 H, 8^{\prime} H\right)$-dione (4d). Yield 65.0\%; mp: $230-$ $232^{\circ} \mathrm{C} ;{ }^{1} \mathrm{H}$ NMR (500 MHz, DMSO-d6): 13.34 (s, 2H, NH), $9.89(\mathrm{~d}, J=7.0 \mathrm{~Hz}, 2 \mathrm{H}), 7.42(\mathrm{~s}, 2 \mathrm{H}), 7.36-7.29(\mathrm{~m}, 6 \mathrm{H})$, 6.95-6.92 (m, 6H), $4.68\left(\mathrm{br}, 4 \mathrm{H}, 2 \mathrm{CH}_{2}-\mathrm{Ph}\right), 3.75(\mathrm{~m}, 2 \mathrm{H}$, $\left.\mathrm{CH}\left(\mathrm{CH}_{3}\right)_{2}\right), 3.72\left(\mathrm{~s}, 6 \mathrm{H}, \mathrm{OCH}_{3}\right), 1.98\left(\mathrm{~s}, 6 \mathrm{H}, 2 \mathrm{CH}_{3}\right), 1.45(\mathrm{t}$, $\left.J=7.0 \mathrm{~Hz}, 12 \mathrm{H}, 4 \mathrm{CH}_{3}\right) \cdot{ }^{13} \mathrm{C}$ NMR $(125 \mathrm{MHz}$, DMSO-d6): $172.3,162.5,159.2,158.9,149.7,131.2,130.2,129.3,129.1$, $126.6,116.3,114.2,113.9,103.4,55.2,52.7,52.9,26.5,20.6$, 20.2. HR-ESIMS $[\mathrm{M}+\mathrm{H}]^{+}$found 757.34880; calculated $\mathrm{C}_{46} \mathrm{H}_{49} \mathrm{~N}_{2} \mathrm{O}_{8}$ : 757.34889 .

5.3. Representative Procedure for the Synthesis of Hydrazones $(8 a-e$ and $12 a-e)$. A mixture of 2-fluorobenzoic acid (5a) $(1 \mathrm{~g}, 7.13 \mathrm{mmol})$ in $\mathrm{MeOH}(20 \mathrm{~mL})$ was stirred for a few minutes. Concentrated $\mathrm{H}_{2} \mathrm{SO}_{4}(1 \mathrm{~mL})$ was added, and the mixture was refluxed for $12 \mathrm{~h}$. The reaction was monitored by TLC using $n$-hexane, with ethyl acetate as a developing system. $\mathrm{CH}_{2} \mathrm{Cl}_{2}(30 \mathrm{~mL})$ was then added, and the mixture was extracted with distilled $\mathrm{H}_{2} \mathrm{O}(3 \times 20 \mathrm{~mL})$. The organic phase was separated, dried on anhydrous $\mathrm{Na}_{2} \mathrm{SO}_{4}$, and evaporated under vacuum to afford corresponding ester $\mathbf{6 a}$ in almost quantitative yield in oil form $(1.09 \mathrm{~g})$. The oil was then dissolved in $\mathrm{EtOH}$, and $\mathrm{NH}_{2} \mathrm{NH}_{2} \cdot \mathrm{H}_{2} \mathrm{O}$ (3 eq) was added. The mixture was refluxed for $10 \mathrm{~h} . \mathrm{CH}_{2} \mathrm{Cl}_{2}(30 \mathrm{~mL})$ was then added and extracted with distilled $\mathrm{H}_{2} \mathrm{O}(3 \times 20 \mathrm{~mL})$. The organic phase was separated, dried on anhydrous $\mathrm{Na}_{2} \mathrm{SO}_{4}$, and evaporated under vacuum to afford corresponding hydrazide $7 \mathbf{a}$ in very good yield (white solid, $1.02 \mathrm{~g}, 93 \%$ ) and used for next step. (-)-Gossypol (200 mg, $0.38 \mathrm{mmol}$ ) and $\mathrm{ZnCl}_{2}(5 \mathrm{mg})$ were added to the solution of hydrazide $7 \mathbf{a}$ (122 g, $0.80 \mathrm{mmol}$, and $2.1 \mathrm{eq})$ in ethanol $(10 \mathrm{~mL})$. The reaction was stirred at room temperature for $16 \mathrm{~h}$. The resulting precipitate was then filtered and washed with cold methanol and dichloromethane to give hydrazone $\mathbf{8 a}$.

$N^{\prime}, N^{\prime \prime \prime}-\left(\left(1 Z, 1^{\prime} Z\right)-\left((R)-1,1^{\prime} 6,6^{\prime}-\right.\right.$ Tetrahydroxy-5, $5^{\prime}$-diisopropyl-

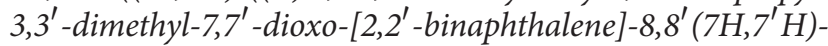
diylidene)bis(methanylylidene))bis(2-fluorobenzohydrazide) (8a). Yield 50.4\%; mp: $236-238^{\circ} \mathrm{C} ;{ }^{1} \mathrm{H}$ NMR $(500 \mathrm{MHz}$, DMSO-d6): 14.53 (s, 2H, NH), 12.32 (s, 2H, NH), 10.09 (s, 
$2 \mathrm{H}), 8.82(\mathrm{~s}, 2 \mathrm{H}), 8.17(\mathrm{~s}, 2 \mathrm{H}), 7.69(\mathrm{~m}, 2 \mathrm{H}), 7.61-7.56(\mathrm{~m}$, $4 \mathrm{H}), 7.36-7.32(\mathrm{~m}, 4 \mathrm{H}), 3.91\left(\mathrm{~m}, 2 \mathrm{H}, \mathrm{CH}\left(\mathrm{CH}_{3}\right)_{2}\right), 1.99(\mathrm{~s}, 6 \mathrm{H}$, $\left.2 \mathrm{CH}_{3}\right), 1.48\left(\mathrm{t}, \mathrm{J}=7.0 \mathrm{~Hz}, 12 \mathrm{H}, 4 \mathrm{CH}_{3}\right) .{ }^{13} \mathrm{C} \mathrm{NMR}(125 \mathrm{MHz}$, DMSO-d6): 160.2, 160.0, 158.3, 153.5, 150.8, 149.9, 133.1, 133.0, $132.8,130.3,128.7,127.9,124.7,122.5,122.4,118.8,116.3,116.1$, $115.9,107.3,56.0,20.9,20.5$. HR-ESIMS $[\mathrm{M}+\mathrm{H}]^{+}$found 791.28920; calculated $\mathrm{C}_{44} \mathrm{H}_{41} \mathrm{~F}_{2} \mathrm{~N}_{4} \mathrm{O}_{8}$ : 791.28925 .

$N^{\prime}, N^{\prime \prime \prime}-\left(\left(1 Z, 1^{\prime} Z\right)-\left((R)-1,1^{\prime} 6,6^{\prime}-\right.\right.$ Tetrahydroxy-5, $5^{\prime}$-diisopropyl-

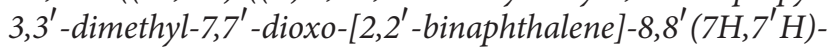
diylidene)bis(methanylylidene))bis(3-fluorobenzohydrazide)

(8b). Yield 63.0\%; mp: $230-233^{\circ} \mathrm{C}$; ${ }^{1} \mathrm{H}$ NMR $(500 \mathrm{MHz}$, DMSO-d6): 14.69 (s, 2H, NH), 12.43 (s, 2H, NH), 10.20 $(\mathrm{s}, 2 \mathrm{H}), 8.83(\mathrm{~s}, 2 \mathrm{H}), 8.19(\mathrm{~s}, 2 \mathrm{H}), 7.79(\mathrm{dd}, J=7.5 \mathrm{~Hz}$, $4 \mathrm{H}), 7.63$ (s, 2H), $7.58(\mathrm{~m}, 2 \mathrm{H}), 7.46-7.42(\mathrm{~m}, 2 \mathrm{H}), 7.69(\mathrm{~m}$, $2 \mathrm{H}), 7.61-7.56(\mathrm{~m}, 4 \mathrm{H}), 7.36-7.32(\mathrm{~m}, 4 \mathrm{H}), 3.91(\mathrm{~m}, 2 \mathrm{H}$, $\left.\mathrm{CH}\left(\mathrm{CH}_{3}\right)_{2}\right), 1.99\left(\mathrm{~s}, 6 \mathrm{H}, 2 \mathrm{CH}_{3}\right), 1.48(\mathrm{t}, J=7.0 \mathrm{~Hz}, 12 \mathrm{H}$, $\left.4 \mathrm{CH}_{3}\right) .{ }^{13} \mathrm{C}$ NMR (125 MHz, DMSO-d6): 162.9, 161.4, 160.9, $153.6,150.7,150.1,143.9,134.9,132.7,130.7,128.7,127.9,123.9$, $118.9,118.7,116.2,114.6,114.4,107.3,56.0,26.0,20.4$.

$N^{\prime}, N^{\prime \prime \prime}-\left(\left(1 Z, 1^{\prime} Z\right)-\left((R)-1,1^{\prime} 6,6^{\prime}-\right.\right.$ Tetrahydroxy-5, $5^{\prime}$-diisopropyl$3,3^{\prime}$-dimethyl-7,7' -dioxo-[2,2' binaphthalene]-8, $8^{\prime}\left(7 \mathrm{H}, 7^{\prime} \mathrm{H}\right)$ diylidene)bis(methanylylidene))bis(4-fluorobenzohydrazide) (8c). Yield 57.9\%; mp: $235-237^{\circ} \mathrm{C} ;{ }^{1} \mathrm{H}$ NMR $(500 \mathrm{MHz}$, DMSO-d6): 14.76 (s, 2H, NH), 12.39 (s, 2H, NH), 10.19 (s, $2 \mathrm{H}), 8.81(\mathrm{~s}, 2 \mathrm{H}), 8.16(\mathrm{~s}, 2 \mathrm{H}), 8.02(\mathrm{~d}, J=8.0 \mathrm{~Hz}, 4 \mathrm{H}), 7.63$ $(\mathrm{s}, 2 \mathrm{H}), 7.37(\mathrm{~d}, \mathrm{~J}=8.0 \mathrm{~Hz}, 4 \mathrm{H}), 3.92\left(\mathrm{~m}, 2 \mathrm{H}, \mathrm{CH}\left(\mathrm{CH}_{3}\right)_{2}\right)$, $2.03\left(\mathrm{~s}, 6 \mathrm{H}, 2 \mathrm{CH}_{3}\right), 1.50\left(\mathrm{t}, J=6.0 \mathrm{~Hz}, 12 \mathrm{H}, 4 \mathrm{CH}_{3}\right) .{ }^{13} \mathrm{C} \mathrm{NMR}$ (125 MHz, DMSO-d6): 165.2, 163.3, 161.7, 153.2, 150.8, 150.1, $143.9,132.7,130.4,129.1,128.64,127.73,118.87,116.15,115.90$, $115.59,115.42,107.37,56.0,26.0,20.4$.

$N^{\prime}, N^{\prime \prime \prime}-\left(\left(1 Z, 1^{\prime} Z\right)-\left((R)-1,1^{\prime} 6,6^{\prime}-\right.\right.$ Tetrahydroxy-5, $5^{\prime}$-diisopropyl-

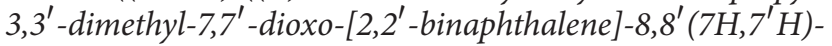
diylidene)bis(methanylylidene))bis(3-methylbenzohydrazide) (8d). Yield 57.8\%; mp: 204-206 ${ }^{\circ} \mathrm{C} ;{ }^{1} \mathrm{H}$ NMR $(500 \mathrm{MHz}$, DMSO-d6): 14.77 (s, 2H, NH), 12.29 (s, 2H, NH), 10.16 (s, $2 \mathrm{H}), 8.81(\mathrm{~s}, 2 \mathrm{H}), 8.80(\mathrm{~s}, 2 \mathrm{H}), 8.12(\mathrm{~s}, 2 \mathrm{H}), 7.75-7.72(\mathrm{~m}$, $4 \mathrm{H}), 7.62(\mathrm{~s}, 2 \mathrm{H}), 7.40(\mathrm{~m}, 4 \mathrm{H}), 3.91\left(\mathrm{~m}, 2 \mathrm{H}, \mathrm{CH}\left(\mathrm{CH}_{3}\right)_{2}\right)$, $2.37\left(\mathrm{~s}, 6 \mathrm{H}, 2 \mathrm{CH}_{3}\right), 2.02\left(\mathrm{~s}, 6 \mathrm{H}, 2 \mathrm{CH}_{3}\right), 1.47(\mathrm{t}, J=5.5 \mathrm{~Hz}$, $\left.12 \mathrm{H}, 4 \mathrm{CH}_{3}\right) .{ }^{13} \mathrm{C}$ NMR (125 MHz, DMSO-d6): 165.79, 153.07, $150.72,150.08,137.83,132.59,132.51,128.63,128.39,128.14$, $127.65,124.80,118.84,116.18,107.39,26.60,20.91,20.56$.

$N^{\prime}, N^{\prime \prime \prime}-\left(\left(1 Z, 1^{\prime} Z\right)-\left((R)-1,1^{\prime} 6,6^{\prime}-\right.\right.$ Tetrahydroxy-5, $5^{\prime}$-diisopropyl-

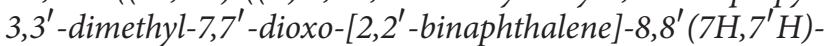
diylidene)bis(methanylylidene))bis(4-methylbenzohydrazide) (8e). Yield 60.4\%; mp: $213-215^{\circ} \mathrm{C}$; ${ }^{1} \mathrm{H}$ NMR $(500 \mathrm{MHz}$, DMSO-d6): 14.81 (s, 2H, NH), 12.28 (s, 2H, NH), 10.18 (s, $2 \mathrm{H}), 8.81(\mathrm{~s}, 2 \mathrm{H}), 8.80(\mathrm{~s}, 2 \mathrm{H}), 8.13(\mathrm{~s}, 2 \mathrm{H}), 7.86(\mathrm{~d}, J=7.5 \mathrm{~Hz}$, $2 \mathrm{H}), 7.45$ (d, $J=7.5 \mathrm{~Hz}, 2 \mathrm{H}), 7.63(\mathrm{~s}, 2 \mathrm{H}), 7.33$ (d, $J=8.0 \mathrm{~Hz}$, $2 \mathrm{H}), 7.28(\mathrm{~d}, J=7.0 \mathrm{~Hz}, 2 \mathrm{H}), 3.92\left(\mathrm{~m}, 2 \mathrm{H}, \mathrm{CH}\left(\mathrm{CH}_{3}\right)_{2}\right), 2.37$ $\left(\mathrm{d}, J=10.5 \mathrm{~Hz}, 6 \mathrm{H}, 2 \mathrm{CH}_{3}\right), 2.02\left(\mathrm{~s}, 6 \mathrm{H}, 2 \mathrm{CH}_{3}\right), 1.47(\mathrm{t}$, $\left.J=5.5 . \mathrm{Hz}, 12 \mathrm{H}, 4 \mathrm{CH}_{3}\right) .{ }^{13} \mathrm{C}$ NMR $(125 \mathrm{MHz}, \mathrm{DMSO}-\mathrm{d} 6)$ : $162.56,152.91,150.72,150.09,142.06,141.68,132.61,129.73$, $129.41,129.02,128.97,127.66,127.16,118.81,116.16,107.41$, 21.01, 20.96, 20.58. HR-ESIMS $[\mathrm{M}+\mathrm{H}]^{+}$found 783.33931; calculated $\mathrm{C}_{46} \mathrm{H}_{47} \mathrm{~N}_{4} \mathrm{O}_{8}: 783.33939$.
$N^{\prime}, N^{\prime \prime \prime}-\left(\left(1 Z, 1^{\prime} Z\right)-\left((R)-1,1^{\prime} 6,6^{\prime}-\right.\right.$ Tetrahydroxy-5, $5^{\prime}$-diisopropyl-

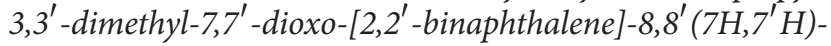
diylidene)bis(methanylylidene))bis(2-(2-fluorophenyl)acetohydrazide) (12a). Yield 51.7\%; mp: 202-204 ${ }^{\circ} \mathrm{C} ;{ }^{1} \mathrm{H}$ NMR (500 MHz, DMSO-d6): 15.26 (s, 2H, NH), 12.89 (s, 2H, NH), 10.83 (s, 2H), 9.61 (s, 2H), 9.03 (s, 2H), 8.44 (s, 2H), 8.23 (m, $2 \mathrm{H}), 8.16(\mathrm{~m}, 2 \mathrm{H}), 8.01(\mathrm{~m}, 4 \mathrm{H}), 4.73$ (brs, $\left.2 \mathrm{H}, \mathrm{CH}\left(\mathrm{CH}_{3}\right)_{2}\right)$, $4.48\left(\mathrm{~s}, 4 \mathrm{H}, \mathrm{CH}_{2}-\mathrm{Ph}\right), 2.83\left(\mathrm{~s}, 6 \mathrm{H}, 2 \mathrm{CH}_{3}\right), 2.31(\mathrm{t}, J=5.0 \mathrm{~Hz}$, $\left.12 \mathrm{H}, 4 \mathrm{CH}_{3}\right) .{ }^{13} \mathrm{C}$ NMR (125 MHz, DMSO-d6): 165.21, 161.55, $159.61,152.13,150.81,149.72,143.83,132.85,131.95,128.98$, $127.65,124.29,122.53,118.63,116.02,115.15,114.98,107.25$, 33.84, 20.56, 20.51. HR-ESIMS $[\mathrm{M}+\mathrm{H}]^{+}$found 819.32005; calculated $\mathrm{C}_{46} \mathrm{H}_{45} \mathrm{~F}_{2} \mathrm{~N}_{4} \mathrm{O}_{8}: 819.32055$.

$N^{\prime}, N^{\prime \prime \prime}-\left(\left(1 Z, 1^{\prime} Z\right)-\left((R)-1,1^{\prime} 6,6^{\prime}-\right.\right.$ Tetrahydroxy-5, $5^{\prime}$-diisopropyl$3,3^{\prime}$-dimethyl-7,7' -dioxo-[2,2'-binaphthalene $]-8,8^{\prime}\left(7 H, 7^{\prime} H\right)$ diylidene)bis(methanylylidene))bis(2-(3-fluorophenyl)acetohydrazide) (12b). Yield 48.7\%; mp: $188-190^{\circ} \mathrm{C} ;{ }^{1} \mathrm{H}$ NMR (500 MHz, DMSO-d6): 14.41 (s, 2H, NH), 12.04 (s, 2H, NH), $9.96(\mathrm{~s}, 2 \mathrm{H}), 8.76(\mathrm{~s}, 2 \mathrm{H}), 8.17(\mathrm{~s}, 2 \mathrm{H}), 7.59$ (s, 2H), 7.37 (m, $2 \mathrm{H}), 7.17(\mathrm{~d}, \mathrm{~J}=7.5 \mathrm{~Hz}, 4 \mathrm{H}), 7.08(\mathrm{~m}, 2 \mathrm{H}), 3.90$ (brs, $2 \mathrm{H}$, $\left.\mathrm{CH}\left(\mathrm{CH}_{3}\right)_{2}\right), 3.62$ (s, 4H, $\left.\mathrm{CH}_{2}-\mathrm{Ph}\right), 1.99$ (s, 6H, 2CH $), 1.48$ $\left(\mathrm{t}, J=7.0 \mathrm{~Hz}, 12 \mathrm{H}, 4 \mathrm{CH}_{3}\right) .{ }^{13} \mathrm{C}$ NMR $(125 \mathrm{MHz}, \mathrm{DMSO}-\mathrm{d} 6)$ : $165.60,163.01,161.07,152.21,150.77,149.73,143.84,138.21$, $132.65,130.21,128.66,127.68,125.26,118.62,115.99,115.81$, $113.55,107.21,40.20,26.55,20.55$.

$N^{\prime}, N^{\prime \prime \prime}-\left(\left(1 Z, 1^{\prime} Z\right)-\left((R)-1,1^{\prime} 6,6^{\prime}-\right.\right.$ Tetrahydroxy-5, $5^{\prime}$-diisopropyl$3,3^{\prime}$-dimethyl-7,7' -dioxo-[2,2'-binaphthalene $]-8,8^{\prime}\left(7 H, 7^{\prime} H\right)$ diylidene)bis(methanylylidene))bis(2-(4-fluorophenyl)acetohydrazide) (12c). Yield 54.8\%; mp: $195-197^{\circ} \mathrm{C} ;{ }^{1} \mathrm{H}$ NMR (500 MHz, DMSO-d6): 14.42 (s, 2H, NH), 12.00 (s, 2H, NH), 9.98 (s, 2H), 8.76 (s, 2H), 8.15 (s, 2H), 7.60 (s, 2H), 7.36-7.30 (m, 4H), 7.17-7.10 (m, 4H), 3.89 (brs, $\left.2 \mathrm{H}, 2 \mathrm{H}, \mathrm{CH}\left(\mathrm{CH}_{3}\right)_{2}\right)$, 3.56 (s, 4H, $\left.\mathrm{CH}_{2}-\mathrm{Ph}\right), 1.98\left(\mathrm{~s}, 6 \mathrm{H}, 2 \mathrm{CH}_{3}\right), 1.47$ (t, $J=5.0 \mathrm{~Hz}$, $\left.12 \mathrm{H}, 4 \mathrm{CH}_{3}\right) .{ }^{13} \mathrm{C}$ NMR (125 MHz, DMSO-d6): 168.83, 166.03, $162.12,160.19,152.11,150.78,149.73,143.83,132.63,128.85$, $127.63,118.62,116.00,115.11,114.97,107.22,40.20,26.50,20.51$.

$N^{\prime}, N^{\prime \prime \prime}-\left(\left(1 Z, 1^{\prime} Z\right)-\left((R)-1,1^{\prime} 6,6^{\prime}-\right.\right.$ Tetrahydroxy-5, $5^{\prime}$-diisopropyl-

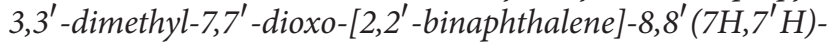
diylidene)bis(methanylylidene))bis(2-(2-chlorophenyl)acetohydrazide) (12d). Yield 52.7\%; mp: $206-208^{\circ} \mathrm{C} ;{ }^{1} \mathrm{H}$ NMR (500 MHz, DMSO-d6): 14.43 (s, 2H, NH), 12.07 (s, 2H, NH), 9.99 (s, 2H), 8.78 (s, 2H), 8.19 (s, 2H), 7.61 (s, 2H), $7.44(\mathrm{~m}$, $4 \mathrm{H}), 7.31(\mathrm{~m}, 4 \mathrm{H}), 3.91$ (brs, $\left.2 \mathrm{H}, 2 \mathrm{H}, \mathrm{CH}\left(\mathrm{CH}_{3}\right)_{2}\right), 3.76(\mathrm{~s}, 4 \mathrm{H}$, $\left.\mathrm{CH}_{2}-\mathrm{Ph}\right), 2.00\left(\mathrm{~s}, 6 \mathrm{H}, 2 \mathrm{CH}_{3}\right), 1.48\left(\mathrm{t}, \mathrm{J}=5.5 \mathrm{~Hz}, 12 \mathrm{H}, 4 \mathrm{CH}_{3}\right)$. ${ }^{13} \mathrm{C}$ NMR (125 MHz, DMSO-d6): 165.07, 152.03, 150.79, $149.71,143.85,133.55,133.41,132.64,132.43,132.15,129.04$, $128.91,128.68,127.63,127.10,118.62,116.02,107.25,38.31,20.55$, 20.5 .

$N^{\prime}, N^{\prime \prime \prime}-\left(\left(1 Z, 1^{\prime} Z\right)-\left((R)-1,1^{\prime} 6,6^{\prime}-\right.\right.$ Tetrahydroxy-5, $5^{\prime}$-diisopropyl$3,3^{\prime}$-dimethyl-7,7' -dioxo-[2,2'-binaphthalene $]-8,8^{\prime}\left(7 H, 7^{\prime} H\right)$ diylidene)bis(methanylylidene))bis(2-(3-chlorophenyl)acetohydrazide) (12e). Yield 53.0\%; mp: $194-196^{\circ} \mathrm{C} ;{ }^{1} \mathrm{H}$ NMR (500 MHz, DMSO-d6): 14.39 (s, 2H, NH), 12.04 (s, 2H, NH), 9.97 (s, 2H), 8.77 (s, 2H), 8.19 (s, 2H), 7.60 (s, 2H), 7.39-7.28 (m, 8H), 3.89 (brs, $2 \mathrm{H}, 2 \mathrm{H}, \mathrm{CH}\left(\mathrm{CH}_{3}\right)_{2}$ ), 3.60 (s, 4H, $\mathrm{CH}_{2}-\mathrm{Ph}$ ), 
$1.99\left(\mathrm{~s}, 6 \mathrm{H}, 2 \mathrm{CH}_{3}\right), 1.47\left(\mathrm{t}, J=5.5 \mathrm{~Hz}, 12 \mathrm{H}, 4 \mathrm{CH}_{3}\right) .{ }^{13} \mathrm{C} \mathrm{NMR}$ (125 MHz, DMSO-d6): 165.58, 152.24, 150.77, 149.72, 143.82, $137.89,132.86,130.15,128.98,128.65,127.87,127.69,126.65$, $118.63,116.00,107.21,40.1,20.55,20.50$. HR-ESIMS $[\mathrm{M}+\mathrm{H}]^{+}$ found 851.26141; calculated $\mathrm{C}_{46} \mathrm{H}_{45} \mathrm{Cl}_{2} \mathrm{~N}_{4} \mathrm{O}_{8}$ : 851.26144.

\section{Conflicts of Interest}

The authors confirm that there are no conflicts of interest related to the contents of this article.

\section{Acknowledgments}

The authors acknowledge the financial support via Project 08/2015/HĐ-NĐT.

\section{References}

[1] N. Howlader, A. M. Noone, M. Krapcho et al., SEER Cancer Statistics Review, 1975-2012, National Cancer Institute, Bethesda, MD, USA, Based on November 2014 SEER data submission, posted to the SEER web site, April $2015 \mathrm{http} / / /$ seer .cancer.gov/csr/1975_2012/.

[2] I. K. Mellinghoff and C. L. Sawyers, "The emergence of resistance to targeted cancer therapeutics," Pharmacogenomics, vol. 3, no. 5, pp. 603-623, 2002.

[3] M. E. Wall and M. C. Wani, "Camptothecin and taxol: discovery to clinic-thirteenth Bruce F. Cain Memorial Award Lecture," Cancer Research, vol. 55, no. 4, pp. 753-760, 1995.

[4] C. L. Oliver, J. A. Bauer, K. G. Wolter et al., "In vitro effects of the BH3 mimetic, (-)-gossypol, on head and neck squamous cell carcinoma cells," Clinical Cancer Research, vol. 10, no. 22, pp. 7757-7763, 2004.

[5] M. Zhang, H. Liu, Z. Tian, B. N. Griffith, M. Ji, and Q. Q. $\mathrm{Li}$, "Gossypol induces apoptosis in human PC-3 prostate cancer cells by modulating caspase-dependent and caspase-independent cell death pathways," Life Sciences, vol. 80, no. 8, pp. 767-774, 2007.

[6] R. M. Mohammad, S. Wang, S. Banerjee, X. Wu, J. Chen, and F. H. Sarkar, "Nonpeptidic small-molecule inhibitor of Bcl-2 and $\mathrm{Bcl}-\mathrm{X}_{L},(-)$-gossypol, enhances biological effect of genistein against BxPC-3 human pancreatic cancer cell line," Pancreas, vol. 31, no. 4, pp. 317-324, 2005.

[7] M. Zhang, H. Liu, R. Guo et al., "Molecular mechanism of gossypol-induced cell growth inhibition and cell death of HT-29 human colon carcinoma cells," Biochemical Pharmacology, vol. 66, no. 1, pp. 93-103, 2003.

[8] D. W. Hahn, C. Rusticus, A. Probst, R. Homm, and A. N. Johnson, "Antifertility and endocrine activities of gossypol in rodents," Contraception, vol. 24, no. 1, pp. 97-105, 1981.

[9] J. Yang, G. Chen, L. L. Li et al., "Synthesis and anti-H5N1 activity of chiral gossypol derivatives and its analogs implicated by a viral entry blocking mechanism," Bioorganic \& Medicinal Chemistry Letters, vol. 23, no. 9, pp. 2619-2623, 2013.

[10] J. Yang, F. Zhang, J. Li et al., "Synthesis and antiviral activities of novel gossypol derivatives," Bioorganic \& Medicinal Chemistry Letters, vol. 22, no. 3, pp. 1415-1420, 2012.

[11] R. J. Radloff, L. M. Deck, R. E. Royer, and D. L. Vander Jagt, "Antiviral activities of gossypol and its derivatives against herpes simplex virus type II," Pharmacological Research Communications, vol. 18, no. 11, pp. 1063-1073, 1986.
[12] G. Tegos, F. R. Stermitz, O. Lomovskaya, and K. Lewis, "Multidrug pump inhibitors uncover remarkable activity of plant antimicrobials," Antimicrobial Agents and Chemotherapy, vol. 46, no. 10, pp. 3133-3141, 2002.

[13] X. S. Liang, A. J. Rogers, C. L. Webber et al., "Developing gossypol derivatives with enhanced antitumor activity," Investigational New Drugs, vol. 13, no. 3, pp. 181-186, 1995.

[14] R. E. Royer, R. G. Mills, L. M. Deck, G. J. Mertz, and D. L. Vander Jagt, "Inhibition of human immunodeficiency virus type I replication by derivatives of gossypol," Pharmacological Research, vol. 24, no. 4, pp. 407-412, 1991.

[15] L. Tai-Shun, R. F. Schinazi, J. Zhu et al., "Anti-HIV-1 activity and cellular pharmacology of various analogs of gossypol," Biochemical Pharmacology, vol. 46, no. 2, pp. 251-255, 1993.

[16] Y. Lu, S. Wu, Y. Yue et al., "Gossypol with hydrophobic linear esters exhibits enhanced antitumor activity as an inhibitor of antiapoptotic proteins," ACS Medicinal Chemistry Letters, vol. 7, no. 12, pp. 1185-1190, 2016.

[17] L. Li, Z. Li, K. Wang et al., "Design, synthesis, and biological activities of aromatic gossypol schiff base derivatives," Journal of Agricultural and Food Chemistry, vol. 62, no. 46, pp. 1108011088, 2014.

[18] Z. Yonghua, C. Xu, L. Yingchao, C. Xueli, and H. Xiaofeng, "Synthesis and biological evaluation of a novel apogossypolone derivative," Letters in Drug Design \& Discovery, vol. 14, pp. 96101, 2017.

[19] Y. Lu, J. Li, C. Dong, J. Huang, H. Zhou, and W. Wang, "Recent advances in gossypol derivatives and analogs: a chemistry and biology view," Future Medicinal Chemistry, vol. 9, no. 11, pp. 1243-1275, 2017.

[20] J. Qiu, L. R. Levin, J. Buck, and M. M. Reidenberg, "Different pathways of cell killing by gossypol enantiomers," Experimental Biology and Medicine, vol. 227, no. 6, pp. 398-401, 2002.

[21] G. Tang, C.-Y. Yang, Z. Nikolovska-Coleska et al., "Pyrogallolbased molecules as potent inhibitors of the antiapoptotic Bcl2 proteins," Journal of Medicinal Chemistry, vol. 50, no. 8, pp. 1723-1726, 2007.

[22] G. Wang, Z. Nikolovska-Coleska, C. Yang et al., "Structurebased design of potent small-molecule inhibitors of antiapoptotic Bcl-2 proteins," Journal of Medicinal Chemistry, vol. 49, no. 21, pp. 6139-6142, 2006.

[23] H.-X. Jiang, X.-X. Cao, H. Huang, and B. Jiang, "An expedient route for the practical preparation of optically active (-)gossypol," Tetrahedron: Asymmetry, vol. 18, no. 20, pp. 24372441, 2007.

[24] P. Przybylski, K. Pyta, J. Stefańska et al., "Synthesis, crystal structures and antibacterial activity studies of aza-derivatives of phytoalexin from cotton plant - gossypol," European Journal of Medicinal Chemistry, vol. 44, no. 11, pp. 4393-4403, 2009.

[25] K. Likhitwitayawuid, C. K. Angerhofer, G. A. Cordell, J. M. Pezzuto, and N. Ruangrungsi, "Cytotoxic and antimalarial bisbenzylisoquinoline alkaloids from Stephania erecta," Journal of Natural Products, vol. 56, no. 1, pp. 30-38, 1993.

[26] C. Kurekci, S. L. Bishop-Hurley, P. E. Vercoe, Z. Durmic, R. A. M. Al Jassim, and C. S. McSweeney, "Screening of Australian plants for antimicrobial activity against Campylobacter jejuni," Phytotherapy Research, vol. 26, no. 2, pp. 186-190, 2012. 

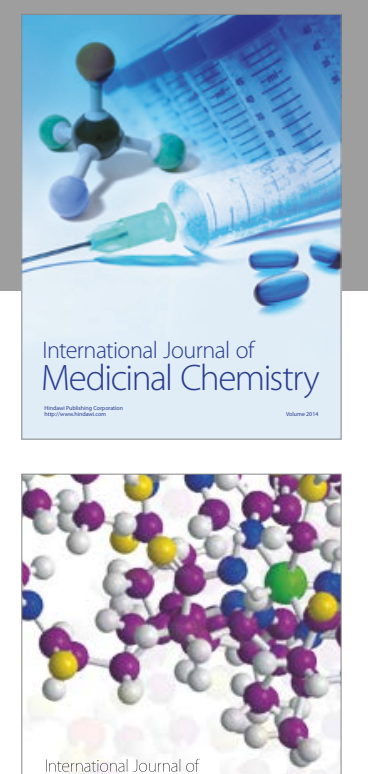

Carbohydrate Chemistry

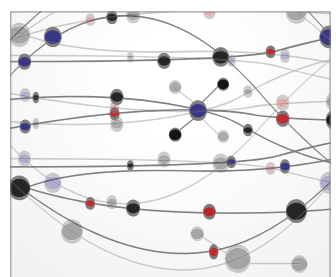

The Scientific World Journal
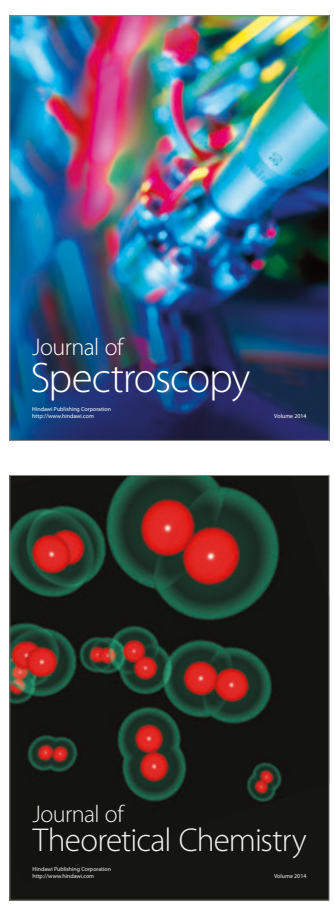
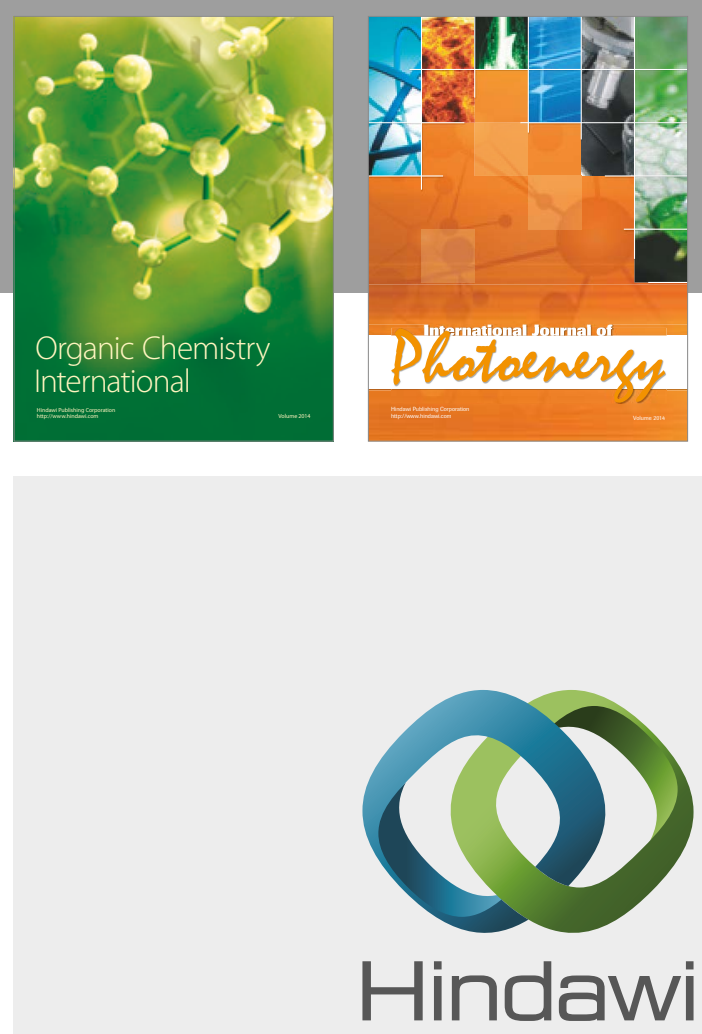

Submit your manuscripts at

https://www.hindawi.com

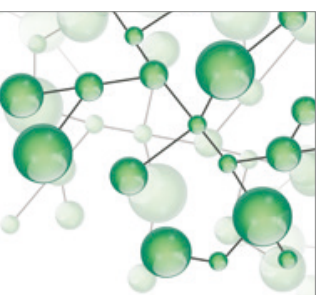

International Journal of

Inorganic Chemistry

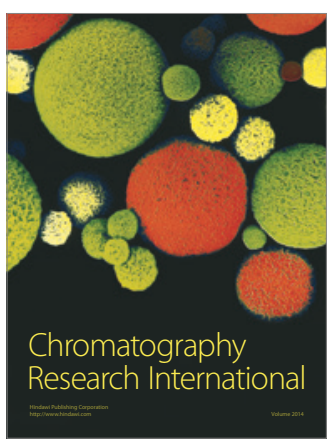

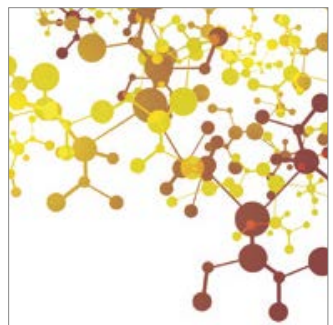

Applied Chemistry
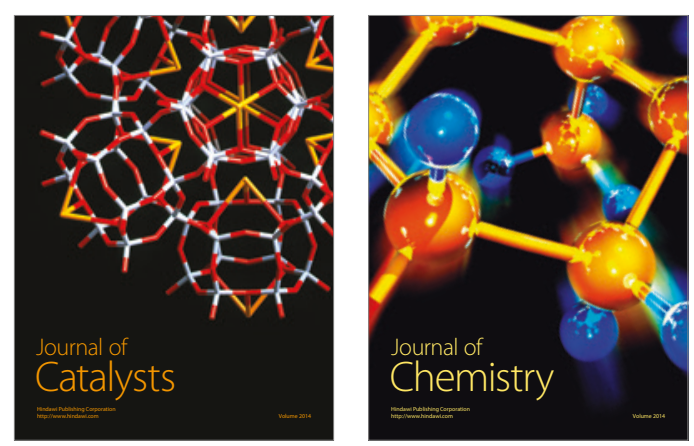
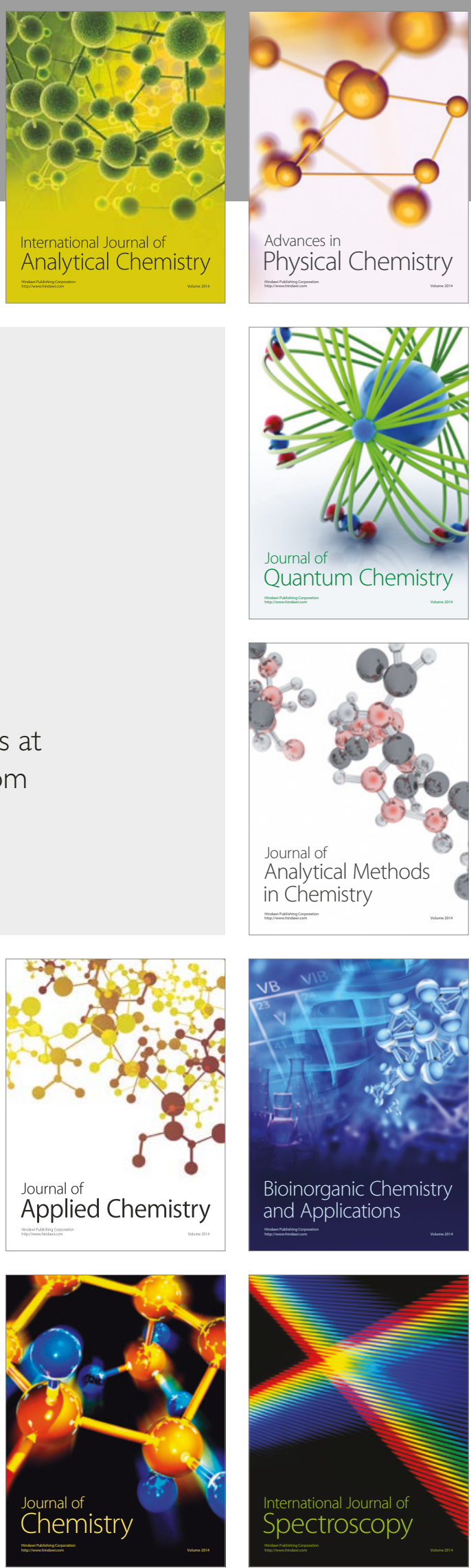